DOI: http://dx.doi.org/10.33846/hn20712

http://heanoti.com/index.php/hn

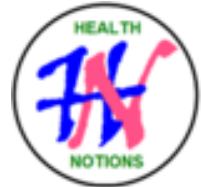

RESEARCH ARTICLE

URL of this article: http://heanoti.com/index.php/hn/article/view/hn20712

\title{
The Use of Role Play Method in Efforts to Improve Capability of Posyandu Cadres
}

\author{
Nurwening Tyas Wisnu ${ }^{1(\mathrm{CA})}$ \\ ${ }^{1(\mathrm{CA})}$ Magetan Midwifery Study Program, Poltekkes Kemenkes Surabaya, Indonesia; \\ nurweningtyas_wisnu@yahoo.co.id (Corresponding Author)
}

\begin{abstract}
Early stimulation, detection and intervention for growth and development of children is a shared responsibility of health and community officials, including cadres of posyandu (integrated service post). The research that has been done is aimed at developing Posyandu cadre, with Role Play approach based on Maternal and child book ( $\mathrm{MCH}$ book). This study was the classroom action research. The population were posyandu cadres in Bendo Sub-district. The sample size was 33, taken by simple random sampling. Instruments used were questionnaire and observation sheet. Descriptive and multivariate analyzes were used. The $38 \%$ of posyandu cadres were of late adulthood, the majority of senior high school (52\%). Knowledge before role play: majority enough (88\%), after role play, good $(73 \%)$. Able to measure weight: good (70\%). Measuring height: good (51.5\%). Ability to measure head circumference well $(84.8 \%)$. Able to detect developments well $82 \%$. Able to perform vision tests with $94 \%$ good. Able to perform hearing test well (100\%). Statistical analysis was no relationship between age and education with pretest knowledge. Conclusion: it was necessary to do coaching to Posyandu cadre continuously, with the use of variation of method to make lesson easier to understand.
\end{abstract}

Keywords: role play; education; children; growth; development

\section{INTRODUCTION}

\section{Background}

Early stimulation, detection and intervention for growth and development of children (ESDIGDC) is is an activity and examination to find early growth disorders and developments in infants and preschool children. Monitoring child development is very important because toddlers are the most perfect period of brain growth. Early detection of child development can be done by community and health institutions.

Early detection of growth disorders of children, can be done at all levels of service. To find poor nutritional status, poor and micro / macrocephaly conditions. At the level of services in the family and community can be done by parents, health workers, BKB (family building children), scribe Early Childhood Education, Child Care, and kindergarten teachers. At this level tools / instruments used are KMS (Card Towards Health $)^{(1)}$

So far only child growth monitoring has been done by health workers (midwives, nurses and doctors). In the development of child growth monitoring is also done by teachers: early childhood, kindergarten and elementary school. This is an attempt to optimize the participation of many people, in monitoring child growth. In some studies indicate that the role of elementary school teachers, kindergarten and early childhood is very important in early detection of developing children under five.

In addition to empowering teachers of early childhood, which is no less important is to empower the community. Therefore, it is necessary to learn with the approach easily understood by Posyandu Cadre, with reference to $\mathrm{MCH}$ book. Expectations of Posyandu cadres have the competence of ESDIGDC, according to their rights and authority.

\section{METHODS}

This research was a kind of clasroom action research, the research was based on problems encountered in the implementation of teaching and learning activities for the purpose of fixing the implementation of teaching and learning activities in accordance with the purpose of research ${ }^{(2)}$. 
This study improving the competence of Posyandu cadres in ESDIGDC, through role play activities with reference to $\mathrm{MCH}$ book. The use of classroom action research because it was done according to the rules of Classroom Action Research, which includes four phases: planning, implementation, observation and reflection ${ }^{(3)}$.

This research was conducted in the Bendo sub-district, Magetan, in April to November 2016. The study population was 36 people in Posyandu in Bendo Bendo sub-district. The sample size was 33, selected by simple random sampling. The variable in this study was the method of role play in improving children's ability in ESDIGDC,

Data were collected using questionnaires and observation sheets. The questionnaire used to measure the knowledge before and after the given material of ESDIGDC. Observation sheet was used to observe activities of the respondent when the implementation of learning.

Step of study began with a pre-test to measure the respondents' knowledge before the given material about ESDIGDC. Then given learning material originating from the $\mathrm{MCH}$ book, such as playing a role in accordance with the plan. Then the respondents had discussions on deepening the material that has been received.

Furthermore, respondents demonstrated the results of discussions with playing a role. Learning concluded by giving the post test questions. During the learning process in the classroom, researchers made observations on the implementation of a class action by using observation sheet. Based on the results of observations made, then did the reflection between researcher and respondent. Discussion of the findings, the difficulties and the problems perceived by the respondents and the research team.

Data were analyzed using descriptive statistics and and bivariate analysis. Descriptive analysis performed to describe the characteristics of the respondent, pretest and posttest results and descriptions of the results of observation $^{(4)}$, in the form of central tendency (mean, median, mode) and frequency. Bivariate analysis used to compare the results of pre and post tests, in the form of paired sample t-test. ${ }^{(4)}$.

\section{RESULTS}

The results showed most respondents age was adolescence $38 \%$, at most high school education $52 \%$. Knowledge about ESDIGDC before treatment: sufficient knowledge: $88 \%$, less than: $6 \%$ and better: $6 \%$. Knowledge of respondents after treatment: $73 \%$ was good knowledge and $27 \%$ was sufficient knowledge. as follows:

The results of ability of respondents during the implementation of role play, after being given treatment

1) The ability to measure weight: capable of doing was $70 \%$ and no capable was $30 \%$.

2) The ability to measure height: capable of doing was $51.2 \%$ and no capable was $48.8 \%$.

3) The ability to measure the circumference of the head: capable was $84.8 \%$, and no capable was $15.2 \%$.

4) The ability to detect development: capable was $82 \%$ and no capable was $18 \%$.

5) The ability to detect visual acuity: capable was $94 \%$ and no capable was $6 \%$.

6) The ability to detect auditory function: capable was $100 \%$ and no capable was $0 \%$.

Statistical analysis showed that: 1) there was no significant correlation between age and the results of pre-test, 2) there was a correlation between the level of education and the results of pre-test.

\section{DISCUSSION}

The most of the respondent's age was a period late adulthood $(38 \%)$. This shows that the age of the greatest opportunities to be actively involved in social activities, is at the end of the adult age. At this time the mother is no longer preoccupied with the task of parenting. At this age humans already have the ability to adjust to daily activities. Respondents will be able to carry out its activities properly, if they are able to adapt and plan activities with good housekeeping ${ }^{(5)}$. Late adult age, about six decades is usually regarded as the dividing line between middle age and old age ${ }^{(6)}$.

The most of the level of education of posyandu cadres was high school (52\%). The level of education is considered sufficient preparation to be a cadre of health. Education is a process of conscious control where changes in behavior resulting in a person. Education is a process that began at birth and lasts throughout life ${ }^{(7)}$.

Knowledge of respondents prior to role play was sufficient (88\%). This is not in line with expectations. Despite their education that the average high school, but respondents do not know their job well. They have not been getting the material on ESDIGDC. If a person has a high level of knowledge, then he will be more critical when facing problems. Knowledge can be acquired either formally or informally. To get a lot of knowledge, a Posyandu cadres should always get guidance from health professionals. Guidance can affect a person's knowledge, so that he had the capacity to do early detection of growth and development of children ${ }^{(8)}$.

After training with role-play method, Posyandu cadres have improved knowledge showed good results by $73 \%$. This illustrates that Posyandu cadres in District Bendo, knowledge became better after the counseling 
method of role play. This means that counseling and guidance from health professionals should be improved, through a variety of methods. Health workers can be an important source to enhance the capabilities and knowledge of volunteers of Posyandu. Health officer may explain the role and duties in terms of the health of children, so that Posyandu cadres have a good knowledge of child development. The hope of cadres capable of giving information to parents as well as the detection of early childhood development ${ }^{(8)}$.

Posyandu cadres better understand the material better counseling, if using a variety of methods. The method used should provide ample opportunities for volunteers to feel important, he's not just as an object. Methods to increase participation, better than the method of monologue or lecture. Currently, the extension method is often done in the form of lectures frequently asked questions, so very little audience participation. With this method of role play, activity centered on audience extension, no longer centered on counseling providers, so that they are better able to understand the context. Posyandu cadres actively engaged in counseling, while the officer acts as a facilitator. This method is designed so that Posyandu cadres interested in learning activities. This method expects Posyandu cadres more active and became a subject in the learning process $^{(2)}$.

Measuring height correctly is very important, because this is a key indicator of nutritional status of children. If an error occurs height measurement, the likelihood of children experiencing malnutrition status / more can not be detected properly ${ }^{(8)}$.

The results of observations of the ability of cadres in measuring the circumference of the head, showed that $84.8 \%$ of the cadres have been able. Extension methods role play, can provide insight into the well head circumference measurements for the cadres. Measurements were done correctly can detect the risk of stunted growth and development of children with accurate ${ }^{(9)}$

The most common error on the child's head circumference measurements, among others, do not measure the circumference of the right, on the forehead, above the ears and spine bulge, error while performing measurements on children who use the hood, as well as the use of the band metelin wrong. Children with early discovery of the possibility of illness in the head, can be done with optimal intervention. Conversely, if the child is late or even not immediately detected abnormalities of the head, then the risk of problems of growth and development can be more complex ${ }^{(11)}$.

The results of observations of the respondent's ability to perform tests the visual acuity was $94 \%$ correct. Posyandu cadres capability for early detection of visual acuity is very important, because the number of impaired vision in Indonesia is still very high. Estimates there are 2.5 billion people in the world have vision problems that can not be corrected, such as hypermetropia, myopia, blurred vision. Problems like this can be on everyone at all ages and ethnic groups ${ }^{(12)}$.

The results showed that, all Posyandu cadres able to test the auditory function. They need to have good knowledge to detect abnormalities in a child's hearing. Hearing loss is a decreased ability to hear in one or both ears ${ }^{(13)}$.

The statistical test showed that there was a significant correlation between level of education and pre-test. Education levels were sufficient but low levels of knowledge. The results also suggest there is a relationship between age and knowledge of the pre-test. This means that the age of cadres bersiko contributed to the knowledge of cadres low. Therefore cadres should continue to be given training and education in order to have a good knowledge and skills.

\section{CONCLUSION}

Based on the results, it can be concluded that there is a relationship between level of education and the results of pretest (knowledge)

\section{REFERENCES}

1. Kemenkes RI. Services for Early Stimulation, Detection and Intervention for Child Growth and Development (Pelayanan Stimulasi Deteksi Intervensi Dini Tumbuh Kembang Anak). Jakarta: Kemenkes RI; 2018;1-2.

2. Wandah Waenawae PS. The Effectiveness of Group Discussion Methods and Role Playing in Improving Indonesian Language Skills of Students of Thammasat University, Thailand Keefektifan Metode (Diskusi Kelompok dan Bermain Peran dalam Meningkatkan Keterampilan Berbahasa Indonesia Mahasiswa Thammasat University, Thailand). Ling Tera. 2015;2(1):84-92.

3. Sari L, Rustiana A. Role Play Models in Improving Learning Outcomes in Basic Competencies Applying the Principles of Excellent Service (Model Bermain Peran Dalam Meningkatkan Hasil Belajar pada Kompetensi Dasar Menerapkan Prinsip-Prinsip Pelayanan Prima). J Pendidik Ekon Din Pendidik. 2013;VIII(2):101-10.

4. Final Kurmod. Metlit_Pusdiklatnakes_2016_rev_April_2016.

5. Muchlisah. Difference in Age of Women When Married (Teenagers and Adults) in Relationship with 
Marriage Adjustment in Makassar City (Perbedaan Usia Wanita Ketika Menikah (Remaja dan Dewasa) dalam Hubungannya dengan Penyesuaian Pernikahan di Kota Makassar). J Psikol. 2012;8(2):106-10.

6. Panjaitan MD. The influence of religiosity on attitudes towards death in the elderly (Pengaruh religiusitas terhadap sikap terhadap kematian pada lansia). Medan: USU; 2010.

7. Tanjung R. The level of education and incentives has a positive and significant effect on the performance of employees of PT Garuda Plaza Hotel Medan (Tingkat pendidikan dan insentif berpengaruh secara positif dan signifikan terhadap kinerja karyawan PT Garuda Plaza Hotel Medan). Medan: USU; 2011.

8. Agustin A. Description of Posyandu Cadre Knowledge in Cipacing Village on Toddler Development (Gambaran Pengetahuan Kader di Posyandu Desa Cipacing tentang Perkembangan Balita). Bandung: FIK UNPAD. 2012;2(2).

9. Utami DF, Ramadani MS. Analysis of Internal and External Factors of the Enhancement of Exclusive Breastfeeding Program at the Pariaman Health Center, Pariaman City (Analisis Faktor Internal dan Eksternal Program Peningkatan Pemberianasi Ekslusif Puskesmas Pariaman, Kota Pariaman). J Kesehat Masy. 2013;7(2):66-74.

10. Susilowati D, G Sevenhausen DK. Social and Anthropometrics Profile of Independent Elderly. Bul Penelit Kesehat. 2005;33(3):132-9.

12. Hutami WD. Prevalence of Visual Acuity Decrease in Students in Class 3-6 Manggis 1 Primary School, Karangasem Bali in 2014 (Prevalensi Penurunan Tajam Penglihatan pada Siswa Kelas 3-6 Sekolah Dasar Negeri 1 Manggis, Karangasem Bali Tahun 2014). Witantra. Intisari Sains Medis. 2016;6(1):102-10.

13. Putra IMCD. Sharpness of Hearing Night Club Workers with Full Music (Tajam Dengar Pada Pekerja Kelab Malam Full Music). e-jurnal Med udayana. 2014;3(5). 